\title{
A new approach for product quality prediction of complex equipment by grey system theory: A case study of cutting tools for CNC machine tool
}

\author{
Pang, J.H. ${ }^{a}$, Zhao, H. ${ }^{a}$, Qin, F.F. ${ }^{b,}{ }^{*}$, Xue, X.B. ${ }^{a}$, Yuan, K.Y. ${ }^{a}$ \\ ${ }^{a}$ College of Mechanical and Electrical Engineering, Wenzhou University, Wenzhou, P.R. China \\ ${ }^{\mathrm{b}}$ School of Information Science and Engineering, Wenzhou Business College, Wenzhou, P.R. China
}

\section{A B S T R A C T}

To compete in total global market, product quality has attracted the attention of manufacturers as an important mean of product differentiation. As effective product quality prediction method is the key technology for quality control system, a new prediction model and calculation method inspired by the grey system theory is proposed in this paper. Our practical evaluation shows that the quality of complex equipment was improved. Firstly, a new method of grey forecasting model for complex equipment was proposed, and the principle and method of grey predictive model with several variables were introduced. Secondly, this article discussed grey system theory model and showed how to use it in the forecasting process. Then, the quality prediction model and method using grey theory were set up with quality characteristics of cutting tools for Computer Numerical Control (CNC) machine tool. Finally, analysis of the test system showed that the applied predicting model and method were feasible and effective. This new method is also applicable to predict product quality of other complex electromechanical products which are composed a number of systems and subsystems.
\end{abstract}

\author{
ARTICLE INFO \\ Keywords: \\ Quality control; \\ Computer numerical control \\ (CNC); \\ Machine tool; \\ Quality prediction; \\ Grey system theory \\ *Corresponding author: \\ E-mail: helloqinfeifei8@sohu.com \\ (Qin, F.F.)
}

Article history:

Received 30 September 2019

Revised 9 December 2019

Accepted 13 December 2019

\section{References}

[1] Farahani, A., Tohidi, H., Shoja, A. (2019). An integrated optimization of quality control chart parameters and preventive maintenance using Markov chain, Advances in Production Engineering \& Management, Vol. 14, No. 1, 5-14, doi: 10.14743/apem2019.1.307.

[2] Bhandari, S.H., Deshpande, S.M. (2011). Analysis of engineered surfaces for product quality monitoring, International Journal of Computers and Applications, Vol. 33, No. 4, 284-292, doi: 10.2316/Journal.202.2011.4. 202-2670.

[3] Çiflikli, C., Kahya-Özyirmidokuz, E. (2012). Enhancing product quality of a process, Industrial Management \& Data Systems, Vol. 112, No. 8, 1181-1200, doi: 10.1108/02635571211264618.

[4] Brahmachary, T.K., Ahmed, S., Mia, M.S. (2018). Health, safety and quality management practices in construction sector: A case study, Journal of System and Management Sciences, Vol. 8, No. 2, 47-64.

[5] Davrajh, S., Bright, G. (2013). Advanced quality management system for product families in mass customization and reconfigurable manufacturing, Assembly Automation, Vol. 33, No. 2, 127-138, doi: 10.1108/0144515131130 $\underline{6636}$.

[6] Brombacher, A., Hopma, E., Ittoo, A., Lu, Y., Luyk, I., Maruster, L., Ribeiro, J., Weijters, T., Wortmann, H. (2012). Improving product quality and reliability with customer experience data, Quality and Reliability Engineering International, Vol. 28, No. 8, 873-886, doi: 10.1002/qre.1277.

[7] Amanna, A., Price, M.J., Thamvichai, R. (2011). Grey systems theory applications to wireless communications, Analog Integrated Circuits and Signal Processing, Vol. 69, No. 2-3, 259-269, doi: 10.1007/s10470-011-9719-1. 
[8] Sosa, M., Mihm, J., Browning, T. (2011). Degree distribution and quality in complex engineered systems, Journal of Mechanical Design, Vol. 133, No. 10, Article ID 101008, doi: 10.1115/1.4004973.

[9] Berget, I., Næs, T. (2002). Optimal sorting of raw materials, based on the predicted end-product quality, Quality Engineering, Vol. 14, No. 3, 459-478, doi: 10.1081/QEN-120001883.

[10] Pan, Y., Lee, J.H. (2003). Recursive data-based prediction and control of product quality for a PMMA batch process, Chemical Engineering Science, Vol. 58, No. 14, 3215-3221, doi: 10.1016/S0009-2509(03)00190-8.

[11] Chetouani, Y. (2009). Model-order reduction based on artificial neural networks for accurate prediction of the product quality in a distillation column, International Journal of Automation and Control, Vol. 3, No. 4, 332-351, doi: 10.1504/IJAAC.2009.026780.

[12] Ding, J., Chai, T., Wang, H. (2011). Offline modeling for product quality prediction of mineral processing using modeling error PDF shaping and entropy minimization, IEEE Transactions on Neural Networks, Vol. 22, No. 3, 408-419, doi: 10.1109/TNN.2010.2102362.

[13] Ahmed, S., Hossain, M.M., Hoque, M.I. (2017). A brief discussion on augmented reality and virtual reality in construction industry, Journal of System and Management Sciences, Vol. 7, No. 3, 1-33.

[14] Ge, Z., Song, Z., Gao, F. (2012). Statistical prediction of product quality in batch processes with limited batchcycle data, Industrial \& Engineering Chemistry Research, Vol. 51, No. 35, 11409-11416, doi: 10.1021/ie202554r.

[15] Hou, W., Zhao, L., Zhang, L., Wang, G. (2013). On-line production quality prediction for a commercial naphtha catalytic reforming process, Information Technology Journal, Vol. 12, No. 18, 4553-4560, doi: 10.3923/itj.2013. 4553.4560.

[16] Zhao, F., Lu, N., Yang, Y. (2013). Product quality prediction method for injection molding process based on operating mode recognition, Huagong Xuebao/CIESC Journal, Vol. 64, No. 7, 2526-2534, doi: 10.3969/j.issn. 0438-1157.2013.07.030.

[17] Gao, K., Khoshgoftaar, T.M., Wald, R. (2014). The use of under- and oversampling within ensemble feature selection and classification for software quality prediction, International Journal of Reliability, Quality and Safety Engineering, Vol. 21, No. 1, doi: 10.1142/S0218539314500041.

[18] Tang, X., Li, Y., Guo, J., Xie, Z. (2014). Final quality prediction for multi-phase batch process based on phase cumulative product quality model, Transactions of the Institute of Measurement and Control, Vol. 36, No. 5, 696708, doi: 10.1177/0142331213501688.

[19] Arsenović, M., Pezo, L., Stanković, S., Radojević, Z. (2015). Factor space differentiation of brick clays according to mineral content: Prediction of final brick product quality, Applied Clay Science, Vol. 115, 108-114, doi: 10.1016/ j.clay.2015.07.030.

[20] Melhem, M., Ananou, B., Djeziri, M., Ouladsine, M. Pinaton, J. (2015). Prediction of the Wafer quality with respect to the production equipments data, IFAC-PapersOnLine, Vol. 48, No. 21, 78-84, doi: 10.1016/j.ifacol.2015.09.508.

[21] Melhem, M., Ananou, B., Ouladsine, M., Pinaton, J. (2016). Regression methods for predicting the product's quality in the semiconductor manufacturing process, IFAC-PapersOnLine, Vol. 49, No. 12, 83-88, doi: 10.1016/ j.ifacol.2016.07.554.

[22] Ribeiro, C.H.P., Miyoshi, S.C., Secchi, A.R., Bhaya, A. (2016). Model predictive control with quality requirements on petroleum production platforms, Journal of Petroleum Science and Engineering, Vol. 137, 10-21, doi: 10.1016/ j.petrol.2015.11.004.

[23] Hao, L., Bian, L., Gebraeel, N., Shi, J. (2017). Residual life prediction of multistage manufacturing processes with interaction between tool wear and product quality degradation, IEEE Transactions on Automation Science and Engineering, Vol. 14, No. 2, 1211-1224, doi: 10.1109/TASE.2015.2513208.

[24] Zheng, R., Pan, F. (2017). Multi-phase support vector regression soft sensor for online product quality prediction in glutamate fermentation process, American Journal of Biochemistry and Biotechnology, Vol. 13, No. 2, 90-98, doi: 10.3844/ajbbsp.2017.90.98.

[25] Yang, Z., Zhu, D., Chen, C., Tian, H., Guo, J., Li, S. (2018). Reliability modelling of CNC machine tools based on the improved maximum likelihood estimation method, Mathematical Problems in Engineering, Vol. 2018, Article ID 4260508, doi: $10.1155 / 2018 / 4260508$.

[26] Bai, Y., Wang, P., Xie, J. (2014). Optimization of urban water supply schemes based on grey system theory, International Journal of Control and Automation, Vol. 7, No. 9, 239-246, doi: 10.14257/ijca.2014.7.9.20.

[27] Longstaff, A.P., Fletcher, S., Parkinson, S., Myers, A. (2013). The role of measurement and modelling of machine tools in improving product quality, International Journal of Metrology and Quality Engineering, Vol. 4, No. 3, 177184, doi: 10.1051/ijmqe/2013054.

[28] Nazifa, T.H., Ramachandran, K.K. (2018). Exploring the role of information sharing in supply chain management: A case study, Journal of System and Management Sciences, Vol. 8, No. 4, 13-37.

[29] Chuang, T.-F., Chang, Y.-H. (2014). Comparison of physical characteristics between Rana latouchtii and Rana adenopleura using grey system theory and artificial neural network, Ecological Engineering, Vol. 68, 223-232, doi: 10.1016/j.ecoleng.2014.03.038.

[30] Bettayeb, B., Bassetto, S.J., Sahnoun, M. (2014). Quality control planning to prevent excessive scrap production, Journal of Manufacturing Systems, Vol. 33, No. 3, 400-411, doi: 10.1016/j.jmsy.2014.01.001.

[31] Lee, Y.-C., Wu, C.-H., Tsai, S.-B. (2014). Grey system theory and fuzzy time series forecasting for the growth of green electronic materials, International Journal of Production Research, Vol. 52, No. 10, 2931-2945, doi: 10.1080 00207543.2013 .857057$.

[32] Sang, G., Shi, K., Liu, Z., Gao, L. (2014). Missing data imputation based on grey system theory, International Journal of Hybrid Information Technology, Vol. 7, No. 2, 347-356, doi: 10.14257/ijhit.2014.7.2.30.

[33] Zhou, Z., Sang, N. (2012). Image edge detection algorithm based on grey system theory, International Journal of Digital Content Technology and its Applications, Vol. 6, No. 23, 782-789. 
[34] Shao, Z. (2012). The evaluation on green textile production system based on grey theory, International Journal of Advancements in Computing Technology, Vol. 4, No. 2, 65-71.

[35] Tserng, H.P., Ngo, T.L., Chen, P.C., Tran, L.Q. (2015). A grey system theory-based default prediction model for construction firms, Computer-Aided Civil and Infrastructure Engineering, Vol. 30, No. 2, 120-134, doi: 10.1111/ mice.12074. 


\title{
APEM
}

\section{Nov pristop za napovedovanje kakovosti izdelkov zapletene opreme s teorijo sivih sistemov: Študija primera rezalnega orodja za CNC obdelovalne stroje}

\author{
Pang, J.H. ${ }^{a}$, Zhao, H. ${ }^{a}$, Qin, F.F. ${ }^{b,}{ }^{*}$, Xue, X.B. ${ }^{a}$, Yuan, K.Y. ${ }^{a}$ \\ ${ }^{a}$ College of Mechanical and Electrical Engineering, Wenzhou University, Wenzhou, P.R. China \\ ${ }^{\mathrm{b}}$ School of Information Science and Engineering, Wenzhou Business College, Wenzhou, P.R. China
}

\section{POVZETEK}

Za doseganje konkurenčnosti na svetovnem trgu so proizvajalci prepoznali kakovost kot pomembno sredstvo za diferenciacijo izdelkov. Ker je učinkovita metoda napovedovanja kakovosti izdelkov ključna tehnologija pri nadzoru kakovosti, sta $\mathrm{v}$ tem prispevku predlagana nov model napovedovanja in metoda izračuna, ki temelji na teoriji sivih sistemov. Naše praktično vrednotenje kaže, da se je kakovost zapletene opreme izboljšala. Najprej je bila predlagana nova metoda sivega napovedovanja za zapleteno opremo, uvedena pa sta načelo in metoda sivega napovedovalnega modela $\mathrm{z}$ več spremenljivkami. V članku je obravnavan model teorije sivih sistemov in prikazana je uporaba $\mathrm{v}$ postopku napovedovanja. Nato sta bila model napovedovanja kakovosti in metoda s sivo teorijo uporabljena s kakovostnimi značilnostmi rezalnega orodja za računalniško krmiljen (CNC) obdelovalni stroj. Analiza testnega sistema je pokazala, da sta uporabljeni model in metoda napovedovanja izvedljiva in učinkovita. Predlagana metoda je uporabna tudi za napovedovanje kakovosti drugih zapletenih elektromehanskih izdelkov, ki so sestavljeni iz več sistemov in podsistemov.

\section{PODATKI O ČLANKU}

Ključne besede:

Nadzor kakovosti;

Računalniško numerično krmiljenje (CNC);

Obdelovalni stroj;

Napoved kakovosti;

Teorija sivih sistemov

*Kontaktna oseba:

E-mail: helloqinfeifei8@sohu.com (Qin, F.F.)

Zgodovina članka:

Prejet 30. septembra 2019

Popravljen 9. decembra 2019

Sprejet 13. decembra 2019 